\title{
LIZARDS AND SNAKES (LEPIDOSAURIA, SQUAMATA) FROM THE LATE QUATERNARY OF THE STATE OF CEARÁ IN NORTHEASTERN BRAZIL
}

\author{
Annie Schmaltz Hsiou', Paulo Victor de Oliveira², Celso Lira Ximenes³, and \\ Maria Somália Sales Viana ${ }^{4}$
}

\begin{abstract}
We present the first formal report on the squamate assemblage from Parque Nacional de Ubajara. This park contains the most important cave complex in the state of Ceará in northeastern Brazil, called Província Espeleológica de Ubajara. The material comes from the Urso Fóssil cave at Pendurado Hill. All previously reported fossil remains found in this cave are tentatively attributed to the Quaternary (late Pleistoceneearly Holocene). Probably only Arctotherium brasiliense represents a relictual fossil bear from the late Pleistocene megafauna. The taxa recognized in this paper belong to Tropidurus sp., Ameiva sp., cf. Epicrates, and cf. Crotalus durissus, adding to the knowledge of the Brazilian Quaternary squamate fauna as a whole, and contribute to a major taxonomic refinement of the squamate assemblages from the early Holocene of northeastern Brazil.
\end{abstract}

\section{INTRODUCTION}

The Brazilian Quaternary record of Squamata (i.e, lizards, amphisbaenians, and snakes) has been documented mainly in the southeast and northeast regions, with several taxa correlated to the current Brazilian herpetofauna (Camolez and Zaher, 2010; Hsiou, 2010). Many records, however, have not been formally studied and described (Lund, 1840; Paula-Couto, 1978; Lino et al., 1979; BarrosBarreto et al., 1982; Guérin, 1991; Guérin et al., 1993; Faure et al., 1999) and their taxonomic and systematic status remains unclear.

Some of the most diverse squamate faunas from the late Pleistocene-Holocene of Brazil were recently studied. The fossils were collected in caves and rock shelters in the states of Bahia (northeastern Brazil), Goiás, Mato Grosso (midwestern Brazil), Minas Gerais, and São Paulo (southeastern Brazil; Camolez and Zaher, 2010). A large number of lizards (Tropiduridae, Leiosauridae, Polychrotidae, Teiidae, and Anguidae), snakes (Boidae, Colubridae, Viperidae, and Elapidae) and amphisbaenians (Amphisbaenidae) were described, and the majority of fossils were attributed to extant neotropical species (Camolez and Zaher, 2010). All fossils were identified based on osteological comparison with extant species. However, there is only a single record of snakes (Viperidae) from the late Pleistocene of southwestern Brazilian Amazonia (Hsiou and Albino, 2011). Beyond these records, some extinct species including two amphisbaenians, Amphisbaena braestrupi and $A$. laurenti, were reported from the late Pleistocene-Holocene of Lagoa Santa region, Minas Gerais State (Gans and Montero, 1998), as was the extinct teiid lizard Tupinambis uruguaianensis, from the late Pleistocene of the Touro Passo Formation, Rio Grande do Sul State, southern Brazil (Hsiou, 2007).
Recent fieldwork was undertaken at Parque Nacional de Ubajara, where the most important cave complex in the state of Ceará in northeastern Brazil is located, part of a notable karstic system (Oliveira, 2010). Small mammals, such as bats, rodents, and marsupials (Ximenes and Machado, 2004), were among the taxa recorded. Other records include artiodactyls (deer and peccaries), perissodactyls (tapirs), xenarthrans (armadillos), and felids (Ximenes and Machado, 2004; Oliveira, 2010), as well as a single member of the late Pleistocene megafauna, the fossil bear Arctotherium brasiliense (Trajano and Ferrarezzi, 1995). Other records are from deposits in tanques (natural depressions formed in granitic rocks that accumulate sediments and fossils), such as undetermined remains of lizards and snakes reported by Paula-Couto (1980) as being recorded from Pleistocene deposits of the Itapipoca region.

Recently, Hsiou et al. (2009) briefly reported on some snake vertebrae of the families 'Colubridae' and Viperidae from the late Quaternary in Província Espeleológica de Ubajara. Their report did not contain stratigraphic data (see also Trajano and Ferrarezzi, 1995; Ximenes and Machado, 2004) or radiometric (geochronologic) control. Here we describe new material from the early Holocene in the state of Ceará in Brazil based on the most recent

\footnotetext{
${ }^{1}$ Departamento de Biologia, FFCLRP, Universidade de São Paulo; Av. Bandeirantes 3900, Ribeirão Preto-SP, Brazil. anniehsiou@ffclrp.usp.br

${ }^{2}$ Programa de Pós-Graduação em Geociências/CNPq, Departamento de Geologia, Centro de Tecnologia e Geociências da Universidade Federal de Pernambuco (UFPE); Av. Acadêmico Hélio Ramos, s/n - Cidade Universitária, CEP 50740-530, Recife-PE, Brasil.victoroliveira.paleonto@gmail.com

${ }^{3}$ Museu de Pré-História de Itapipoca (MUPHI); Avenida Anastácio Braga, 349, 62500-000, Itapipoca- CE, Brasil.clx.ximenes@gmail.com

${ }^{4}$ Laboratório de Paleontologia, Museu Dom José, Universidade Estadual Vale do Acaraú (UVA); Av. Dom José, 878, CEP 62010-190, Sobral-CE, Brasil. somalia_viana@hotmail.com
} 


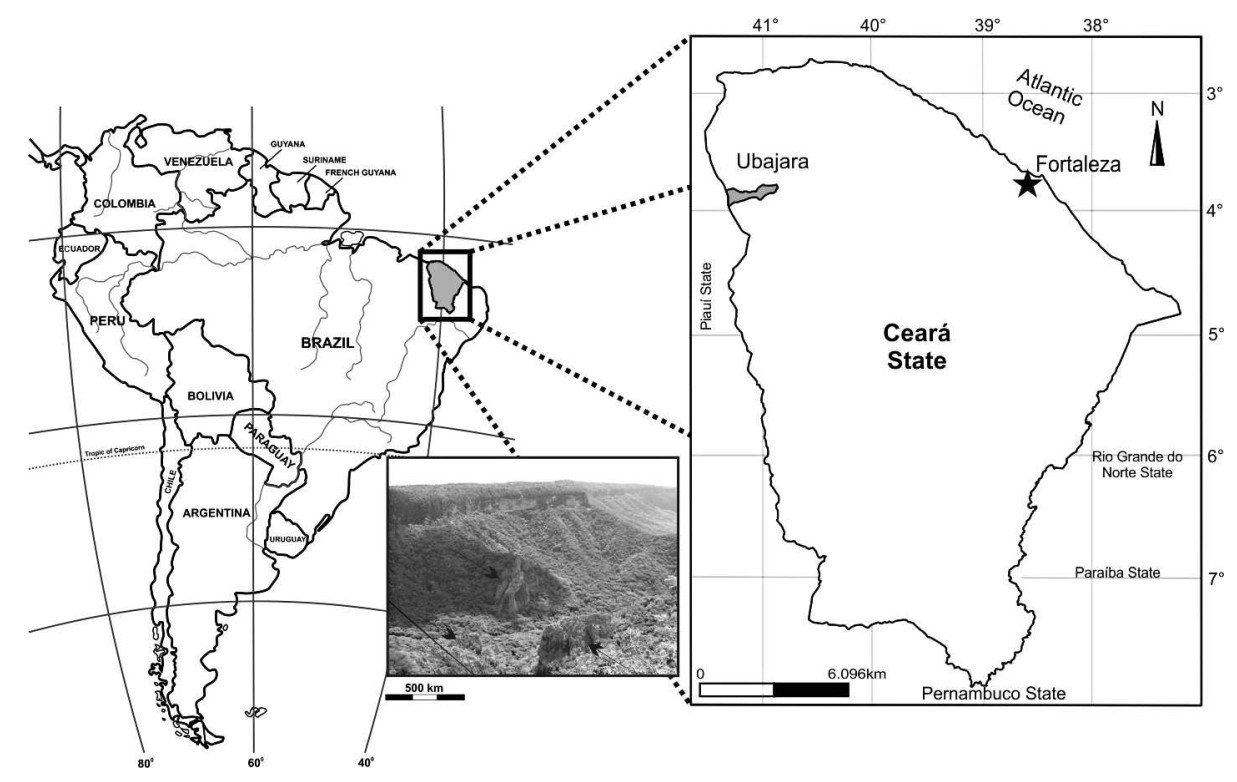

Figure 1. Location map of late Quaternary of Província Espeleológica de Ubajara, Ceará State, Brazil.

fieldwork done in the Ubajara region, during July 2009, with precise stratigraphic and radiometric control.

\section{Location And Geological Setting}

The Parque Nacional de Ubajara is located in Ubajara Municipality (Fig. 1), in Ibiapaba Cuesta in the northwestern portion of the state of Ceará (northeastern Brazil), which possesses a notable karst system. The speleological province of the Ubajara region consists of nine limestone hills with fourteen known caves (IBAMA, 2002). The limestone rock cropping out in the region corresponds to the Frecheirinha Formation of the Ubajara Group, Neoproterozoic of the Ubajara Graben (Quadros, 1996; CPRM, 2003). The Ubajara Group has an unconformable contact with the rocks of the Serra Grande Group, Silurian-Devonian of the Parnaíba Basin (Nascimento et al., 1981). Among the limestone hills in the studied area, the Pendurado Hill includes two important fossiliferous caves: Urso Fóssil and Pendurado.

All fossil remains are attributed to the Quaternary (late Pleistocene-early Holocene), however, the fossil bear Arctotherium brasiliense is probably the only relict in this fauna of the Pleistocene megafauna (Trajano and Ferrarezzi, 1995), found at Urso Fóssil cave $\left(03^{\circ} 49^{\prime} 58^{\prime \prime} \mathrm{S}, 40^{\circ} 53^{\prime} 34.4^{\prime \prime} \mathrm{W}\right)$. The material studied was found in one room of this cave, called Sala de Entrada. A controlled stratigraphic excavation in this room exposed three layers of sedimentary deposits, and all fossil remains belong to the early Holocene. A geological section provided information about unconsolidated accumulations of allochthonous (biogenic and siliciclastic from outside the cave) and autochthonous (generated inside the cave) material. The stratigraphic layers include sediments from the bottom to top (Fig. 2):
Layer 1 has a thickness of $0.20 \mathrm{~m}$ and is comprised of carbonaceous silt-clay sediments, containing smaller autochthonous fragments of limestone and large, angular fragments of speleothems. In this layer, there are shells of freshwater clams and several carbonized bone fragments. As in layer 2, a sample was collected for thermoluminescence dating; more details can be found in Oliveira et al. (in press). Remains of squamate reptiles and mammals such as Didelphimorphia, Xenarthra, Rodentia, and Artiodactyla were found.

Layer 2 has a thickness of about $0.35 \mathrm{~m}$ and is composed of light gray clay containing autochthonous fragments of limestone $(>2 \mathrm{~cm})$, some small geodes, and fragments of stalactites (approximately $10 \mathrm{~cm}$ diameter) and other speleothems, in some cases, showing concentrations of iron oxide. The top of the layer contains a high concentration of two types of undetermined seeds. At the bottom of the layer, some complete shells of freshwater clams and several fragments of shells had accumulated. There are small feces covered by powdered carbonate, but still unconsolidated. Some $20 \mathrm{~cm}$ from the top of this level, sediment samples were collected in PVC pipe for thermoluminescence dating, and below that, samples were obtained for recovery of palynomorphs. Gastropods and several fragments of Didelphimorphia, Xenarthra, and Rodentia, were collected. Layer 3, with a $0.15 \mathrm{~m}$ thickness, is composed of light yellowish, silty-clay sediments of carbonate-rich composition, containing small autochthonous fragments $(0.5-1 \mathrm{~cm})$ of amorphous and angular limestone, and a great amount of recent seeds and fecal matter.

\section{Material And Methods}

The material studied includes isolated dentaries and vertebrae deposited in the collection of Museu Dom José

Journal of Cave and Karst Studies, December 2012 •263 


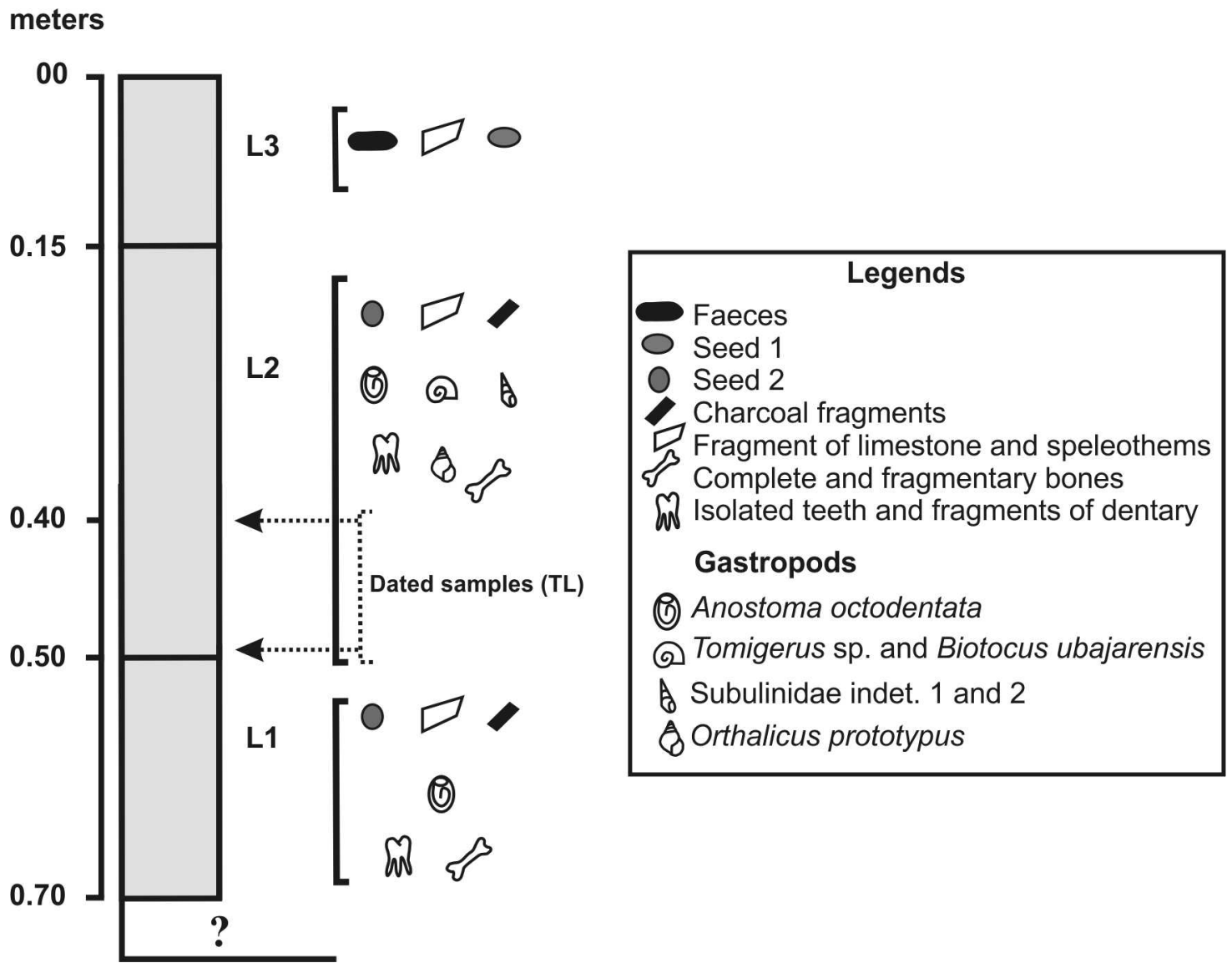

Figure 2. Stratigraphic section showing the layers L1, L2 and L3; and their associated fossils.

(MDJ), in the State Ceará, Brazil. The material consists of two lizard dentaries (MDJ R-004 and 005) and five vertebrae of snakes (MDJ R-006, 020, 024, 026, and 027). The osteological nomenclature and systematics follow Estes (1983), Presch (1974), Estes et al. (1988), Frost et al. (2001a,b), Nydam and Cifelli (2002), and Nydam et al. (2007) for lizards; and Auffenberg (1963), Hoffstetter and Gasc (1969), Rage (1984), Zaher (1999), and Holman (2000) for snakes.

\section{Systematic Paleontology}

SQUAMATA Oppel, 1811

IGUANIA Cope, 1864

TROPIDURIDAE Frost and Etheridge 1989 sensu Frost, Janies, and Titus, 2001a

Tropidurus Wied, 1824

Tropidurus sp.

(Fig. 3)

Material: MDJ R-005, complete right dentary.

Stratigraphic provenance: Parque Nacional de Ubajara, Pendurado Hill, Urso Fóssil Cave, Sala da Entrada, layer 1 (TL 8,200 \pm 980 years BP), early Holocene.

Description: MDJ R-005 is a complete and delicate right dentary with four mental foramina in labial view. The dentary bears thirteen pleurodont teeth preserved in eighteen tooth positions. The mesial teeth are anteriorly inclined and unicuspid. The distal ones are tricuspid, with two accessory cusps, a mesial and a distal one, smaller than the main central cusp. Under the last two posterior teeth, the subdental shelf of the dentary possesses a notch that extends obliquely until the last teeth (Camolez and Zaher, 2010). The symphysis is small and slightly dorsally oriented. Meckel's groove is extensively closed, with an anterior opening restricted to an elongate foramen and a posterior notch under the last two distal tooth positions. The posterior process of the dentary is long when compared to the total size of the dentary. In labial view, the dorsal margin of the posterior process of the dentary shows a flattened surface, for the contact with the anterior process of the coronoid.

Discussion: Species of Tropidurus are widely distributed in open areas in the tropical and subtropical regions, from southern Venezuela east through the Guianas to northeastern Brazil, and from there southwest of the Amazonian region to eastern Bolivia, northernmost Uruguay, and central Argentina (Etheridge, 1964; Ávila-Pires, 1995; Frost et al., 2001b). There are four species groups formally diagnosed within the genus: $T$. spinolusus group, the $T$. borgeti group, the $T$. semitaeniatus group, and the $T$. 

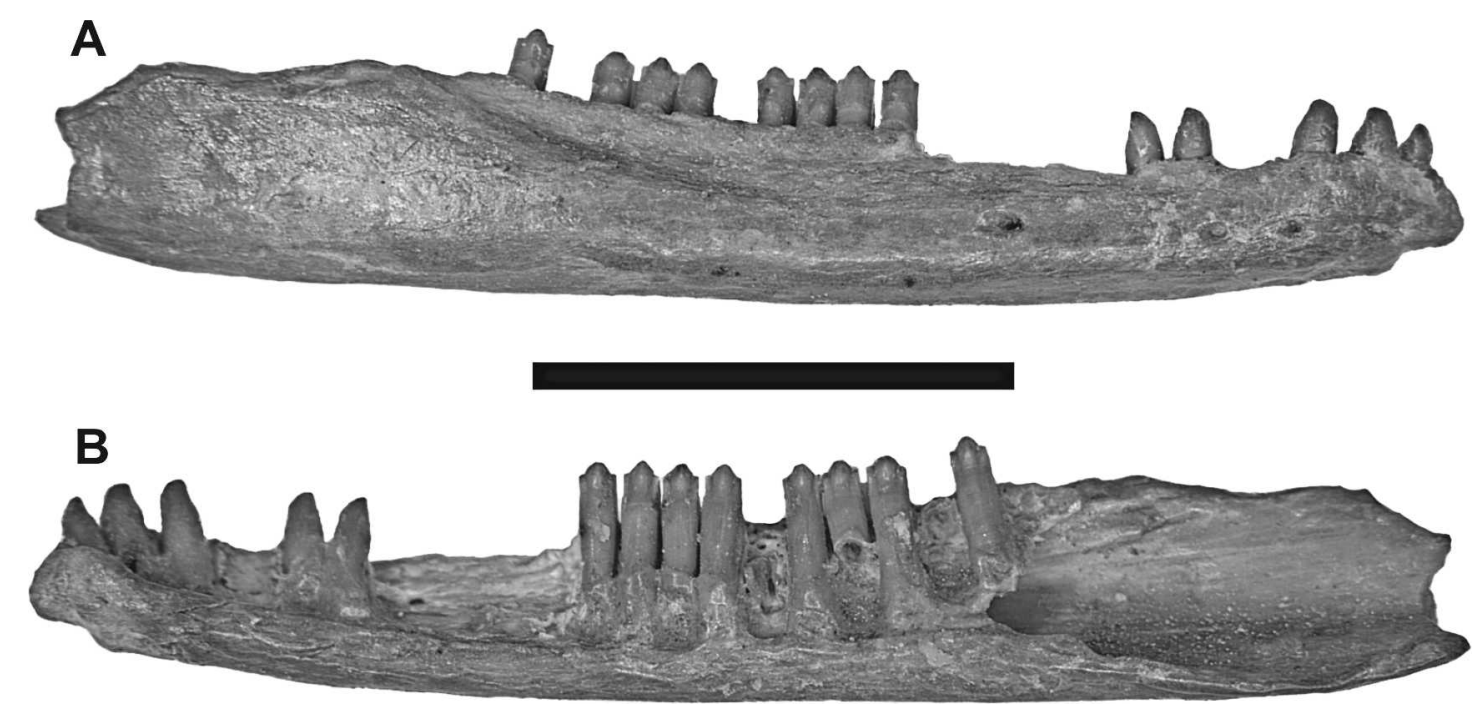

Figure 3. Tropidurus sp. complete right dentary, MDJ R-005: A, labial view; B, lingual view. Scale bar $=10 \mathrm{~mm}$.

torquatus group (Frost et al., 2001b). Attribution to the species level of MDJ R-005 was not possible; but the presence of a longitudinal impression of the labial surface of the posterior part of the dentary, which rises posteriorly (slight "erosion" of the alveolar shelf) should be an apomorphy supporting assignment of MDJ R-005 to the "Tropidurus group" (Frost, 1992; Frost et al. 2001b).

SCLEROGLOSSA Estes, de Queiroz and Gauthier, 1988

SCINCOMORPHA Camp, 1923

TEIIOIDEA Estes, de Queiroz and Gauthier, 1988

TEIIDAE Gray, 1827

TEIINAE Presch, 1974

Ameiva Meyer, 1795

Ameiva sp.

(Fig. 4)

Material: MDJ R-004, incomplete right dentary.

Stratigraphic provenance: Parque Nacional de Ubajara, Pendurado Hill, Urso Fóssil Cave, Sala da Entrada, layer 1 (TL 8,200 \pm 980 years BP), early Holocene.

Description: MDJ R-004 is a robust but incomplete right dentary. Its anterior portion is fragmented at the symphysis, and the ventral, lingual and labial portions also are broken. There are three mental foramina in labial view. The dentary rises posteriorly toward its labial and lingual articulations with the coronoid. Lingually, only the anterior portion of the splenial is preserved. Meckel's groove is restricted to the anterior region of dentary by the development of the subdental shelf showing a straight groove (Brizuela, 2010). There are eleven subpleurodont teeth preserved in sixteen tooth positions, within a sulcus dentalis and with heavy deposits of cementum at tooth bases (Estes et al., 1988; Nydam and Cifelli, 2002). The third mesial tooth preserved is conical and apparently unicuspid, relatively smaller than the distal ones. The fourth tooth is damaged, but two accessories cusps can be seen, a mesial and distal one, both slightly posteriorly oriented. The fifth, sixth, and seventh are replacement teeth within the replacement pit and show two accessory cusps, both cusps being almost vertical and aligned with one another. The eighth tooth is broken at the base. From the ninth to the eleventh tooth, tooth size and interdental spacing increases ("enlarged posterior teeth: a greater degree of molariformy", Estes and Williams, 1984). Two accessory cusps are present, as on the fourth preserved tooth.

Discussion: The genus Ameiva displays a wide geographical distribution, occurring in southern Mexico, Central and South America, and in many Caribbean islands, with different species (Ávila-Pires, 1995; Pianka and Vitt, 2003). The genus has been considered a paraphyletic group (Presch, 1974; Reeder et al., 2002; Giugliano et al., 2006, 2007), although some authors defended monophyly (Hower and Hedges, 2003). Among the Ameiva species, the most studied is A. ameiva, commonly found in open habitats, coastal and forests environments, and frequently seen in perianthropic situations (Ávila-Pires, 1995).

Following Camolez and Zaher (2010), the largest size among small Teiidae (such as Cnemidophorus, Kentropix and Crocodilurus) and the dental morphology would allow referral of MDJ R-004 to the species Ameiva ameiva. Nevertheless, no additional osteological materials have been found to support this attribution. Currently, we cannot identify MDJ R-004 to species.

SERPENTES Linnaeus, 1758

ALETHINOPHIDIA Nopcsa, 1923

MACROSTOMATA Müller, 1831

BOOIDEA Gray, 1825

BOIDAE Gray, 1825 

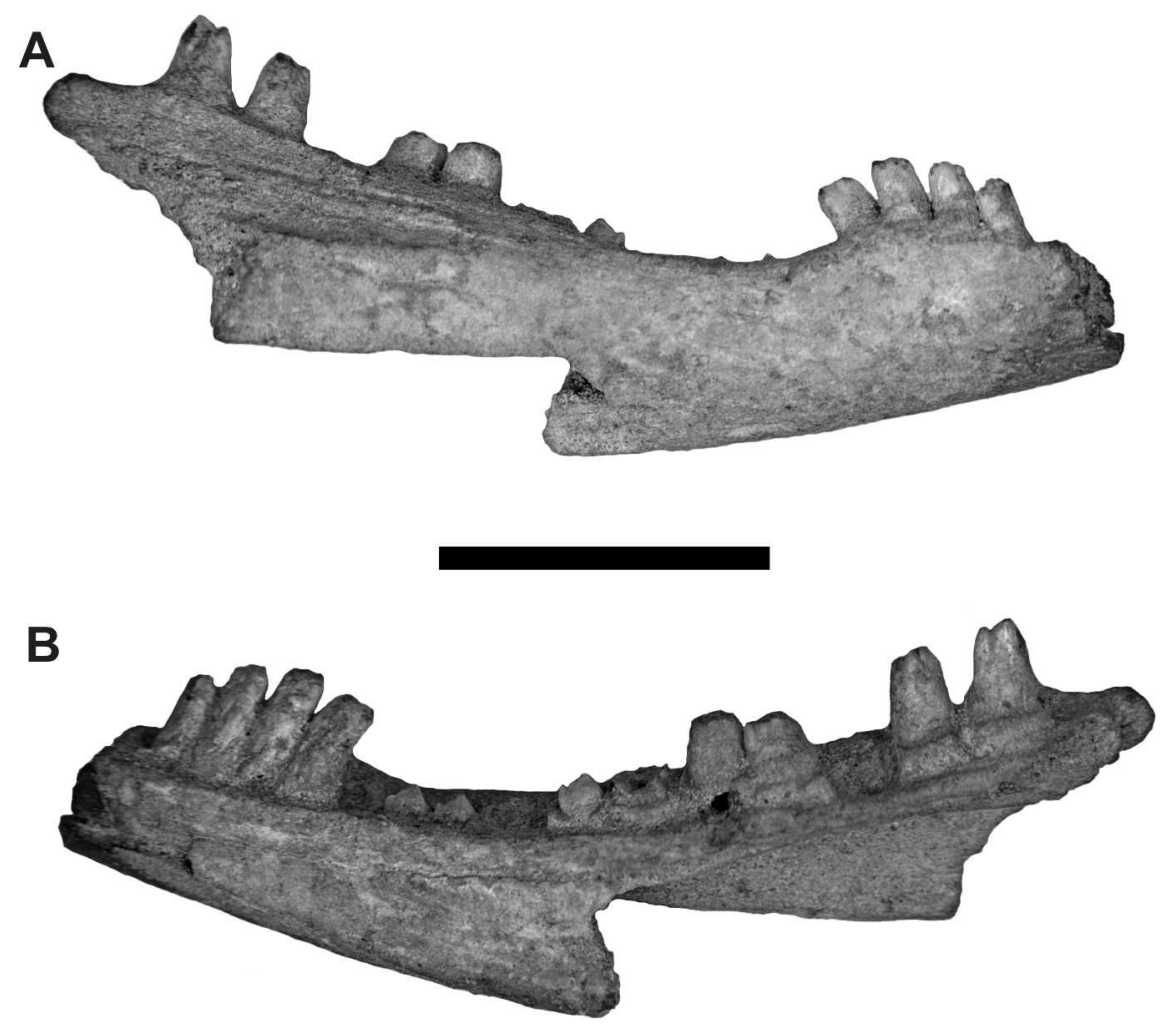

Figure 4. Ameiva sp., incomplete right dentary, MDJ R-004: A, labial view; B, lingual view. Scale bar $=10 \mathrm{~mm}$.

Epicrates Wagler, 1830

cf. Epicrates sp.

(Fig. 5)

Material: MDJ R-020, incomplete midtrunk vertebrae.

Stratigraphic provenance: Parque Nacional de Ubajara, Pendurado Hill, Urso Fóssil Cave, Sala da Entrada, layer 1 (TL 8,200 \pm 980 years BP), early Holocene.

Description: MDJ R-020 lacks most of the dorsal part of the neural arch. The specimen is small, relatively robust and high, with a short centrum. The vertebra probably is a midtrunk vertebra, given the presence of a well marked and anteroposteriorly developed haemal keel. In general view, the prezygapophyses are slightly inclined dorsally, anterolaterally oriented, and display a short prezygapophyseal process. The articular facets of the prezygapophyses are triangular. There are small lateral foramina. The centrum is triangular, widened anteriorly, and rather narrow. A deep paracotylar depression is present to either side of the cotyle, but foramina are absent there. The paradiapophyses are broken, but were apparently robust and oriented dorsoventrally, surpassing the ventral edge of the cotyle. The haemal keel is well-marked and begins on the ventral edge of the cotyle. The subcentral ridges are weakly marked; the subcentral grooves are shallow, but this is more evident in the middle portion of the centrum, lateral to the haemal keel. There is one pair of subcentral foramina.

Discussion: The endemic Neotropical genus Epicrates is currently recognized as a paraphyletic group in relation to
Eunectes, owing to recent studies that found mainland Epicrates in a sister-group relationship with Eunectes (Burbrink, 2005; Noonan and Chippindale, 2006). The genus contains ten species (Kluge, 1989; McDiarmid et al., 1999) and comprises two monophyletic groups (Kluge, 1989; Passos, 2003; Burbrink, 2005; Noonan and Chippindale, 2006; Passos and Fernandes, 2008). An insular group distributed in the West Indian islands contains twenty-one taxa (Henderson and Powell, 2007), whereas Epicrates cenchria (Linnaeus) is a continental endemic (McDiarmid et al., 1999; Passos and Fernandes, 2008). Of the previous nine subspecies of $E$. cenchria, five are now recognized as distinct species E. alvarezi, E. assisi, E. cenchria, E. crassus, and $E$. maurus based on statistically robust delimitation of species boundaries (Passos and Fernandes, 2008). The taxonomic assignment of the specimen described above is based on the following combination of vertebral characters shared with the genera of extant neotropical boines: robust, short and wide vertebra, low inclination of the articular facet of the prezygapophysis (less than $15^{\circ}$ ); short prezygapophyseal process, vertebral centrum short, marked precondylar constriction, haemal keel well developed in the midtrunk vertebrae, and presence of subcentral and lateral foramina (Rage, 2001; Lee and Scanlon, 2002; Szyndlar and Rage, 2003; Albino and Carlini, 2008; Hsiou and Albino, 2009, 2010). Within the neotropical boines, the trunk vertebra is similar to samples from individuals of the genera Epicrates and Corallus, differing from Eunectes and 

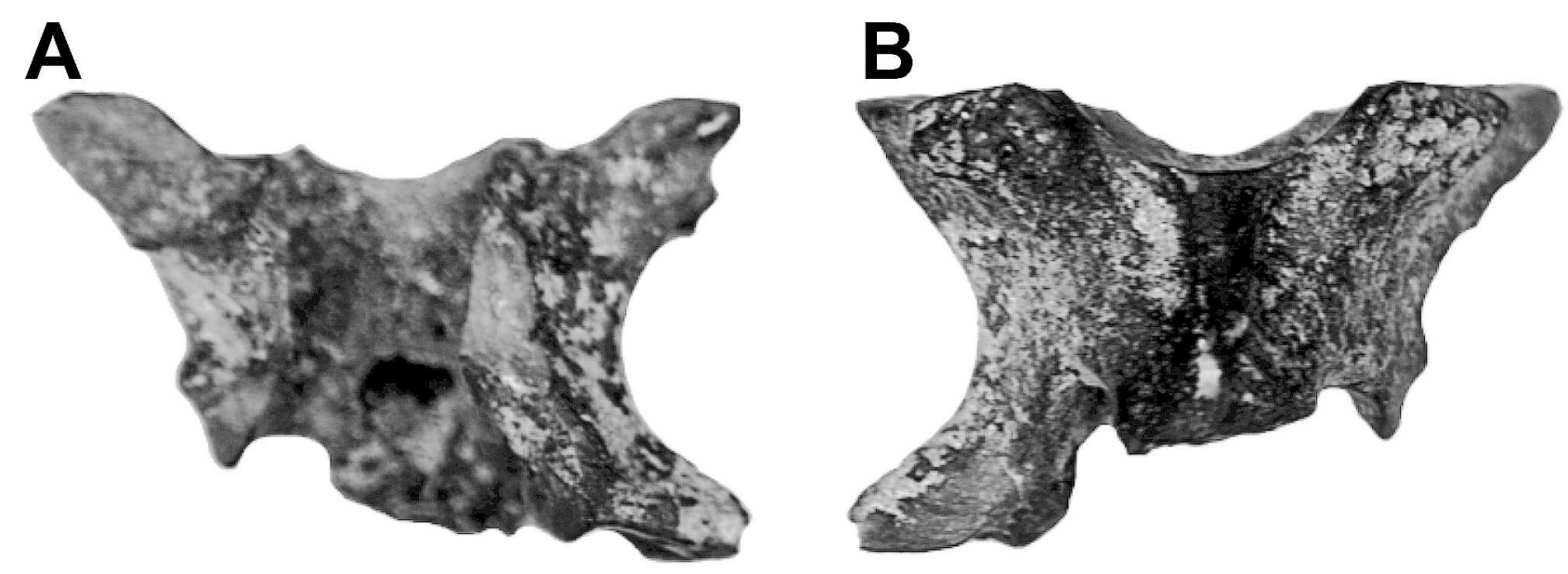

Figure 5. cf. Epicrates sp., incomplete midtrunk vertebra, MDJ R-020:A, dorsal view; B, ventral view. Scale bar = 5 mm.

Boa in its smaller size (Hsiou and Albino, 2009, 2010). According to Hsiou and Albino (2010), Epicrates and Corallus could be distinguished by the morphology of the anterior lobe on the anterior edge of the zygosphene, but MDJ R-020 lacks most of the neural arch. In Corallus the prezygapophyses are mostly horizontal in anterior view, whereas they are relatively more inclined above the horizontal plane in Epicrates (Hsiou and Albino, 2010). For this reason, we tentatively assigned the trunk vertebrae MDJ R-020 to cf. Epicrates.

CAENOPHIDIA Hoffstetter, 1939

COLUBROIDEA Oppel, 1811

VIPERIDAE Oppel, 1811

Crotalus Linnaeus, 1758

Crotalus durissus Linnaeus, 1758

cf. Crotalus durissus

(Fig. 6)

Material: MDJ R-006, 024, 026 and 027, incomplete trunk vertebrae.

Stratigraphic provenance: Parque Nacional de Ubajara, Pendurado Hill, Urso Fóssil Cave, Sala da Entrada, layer 2 (MDJ R-006, TL 8,000 \pm 990 years BP) and layer 1 (MDJ R-024, 026, 027, TL 8,200 \pm 980 years BP), early Holocene.

Description: The preservation of the vertebrae varies among specimens. MDJ R-006 and 024 lack most part of the neural spine, hypapophysis, right prezygapophysis and parapophyseal process, and both paradiapophyses; MDJ R026 lacks the hypapophysis and right prezygapophysis and parapophyseal process; MDJ R-027 lacks most of the neural arch, zygosphene, hypapophysis, and left prezygapohysis and paradiapophysis. The zygosphene is thin and shows a concave anterior margin, with small and dorsally angled articular facets. The neural arch is wider than long, is moderately depressed, and bears a deep posterodorsal notch. The neural canal is subtriangular, low and wide. The articular facets of the prezygapophyses are slender, longer than broad, with the main axis rather laterally oriented. A small prezygapophyseal process projects slightly beyond the articular facets of the prezygapophysis. The paradiapophyses are clearly oriented dorsoventrally as a whole. The diapophysial and parapophysial surfaces are distinct from each other. The paradiapophyses are well developed, with a prominent and spherical diapophysis, distinct from a large and concave parapophysis (seen in MDJ R- 024). A well-developed and strongly inclined parapophyseal process is spatulated projecting anteriorly, and extends clearly beyond the ventral rim of the cotyle. The postzygapophyses are elongated and inclined dorsolaterally. The zygantra are large and deep, with a small foramen within each side of zygantrum. The neural spine is very well developed, high, and considerably elongated anteroposteriorly, seen in MDJ R-026. The interzygapophyseal constriction is deep and curved. Small lateral foramina are evident on the side walls of the neural arch, more or less positioned at the diapophysial level. The cotyle and condyle are nearly circular, and one pair of small paracotylar foramina is evident; one foramen is located on each side of the cotyle, placed in a shallow depression. The centrum is triangular and bears a very prominent hypapophysis (broken in MDJ R-006, 0026, and 027). The centrum is delimited by subcentral ridges that are well defined anteriorly but vanish in the posterior half of the centrum.

Discussion: The Crotalus durissus complex (Neotropical rattlesnakes) occurs in dry areas from Mexico to northern Argentina, but is absent from Central American and Amazonian rainforests, resulting in a highly disjunctive distribution (Wüster et al., 2005). The Brazilian Crotalus durissus complex is represented by a single species, Crotalus durissus, which has a large geographical distribution among the central region of Cerrado, semi-arid and arid environments of northern region, savannas and open areas 

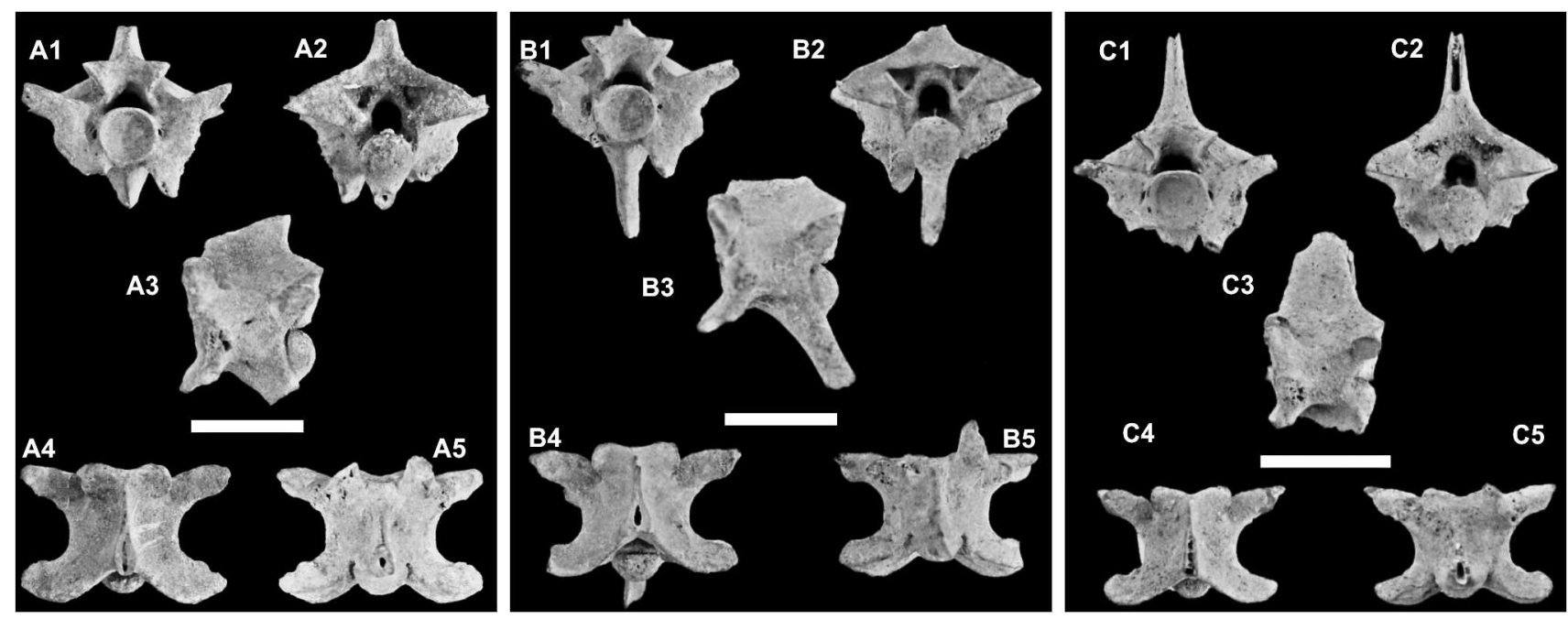

Figure 6. cf. Crotalus durissus, midtrunk vertebrae, MDJ R-006 (A), MDJ R-024 (B), and MDJ R - 026 (C), in anterior (A1-C1), posterior (A2-C2), lateral (A3-C3), dorsal (A4-C4), and ventral (A5-C5) views. Scale bar: $10 \mathrm{~mm}$.

of southern, southeastern and northern regions of Brazil (Melgarejo, 2003). The great distribution of C. durissus in Brazil is represented by the presence of five geographical forms, $C$. d. terrificus, $C$. d. cascavella, $C$. d. collineatus, $C$. d. ruruima, and $C$. $d$. marajoensis. All vertebrae described here share the only vertebral synapomorphy recognized for the Viperidae family: a well-developed and strongly anteroventrally oriented parapophyseal process (Zaher, 1999). However, the distinction among the Brazilian species on osteological features still requires further studies. At present, the vertebrae described here are similar to those of Crotalus durissus in the anterior edge of zygosphene concave, great anteroposterior extent of the neural spine, spatulate parapophyseal process, and presence of small paracotylar foramina. All of these subtle characters can distinguish Crotalus durissus from species of Bothrops, another genus with broad geographical distribution that occurs in most open areas in both northern and southern regions of Brazil.

\section{Concluding Remarks}

The new squamate assemblage from the late Quaternary Província Espeleológica de Ubajara described here comprises the lizard families Tropiduridae (Tropidurus sp.) and Teiidae (Ameiva sp.), and the snake families Boidae (cf. Epicrates sp.) and Viperidae (cf. Crotalus durissus), in addition to undetermined "colubrid" snakes reported by Hsiou et al. (2009). Unfortunately, all specimens are very fragmentary, and specific assignment is not possible. Camolez and Zaher (2010) reported some squamate assemblages from several regions of Brazil, but this work constitutes the first formally described record from the state of Ceará. Hence, the taxa reported in this paper contribute to a better understanding of the Brazilian Quaternary squamate fauna as a whole. Most of the previous records from northeastern Brazil were made based on uninformative reports, lacking a formal description, and their taxonomic validity is still unclear (Paula-Couto, 1980; Guérin, 1991; Guérin et al., 1993; Faure et al., 1999). For this reason, the present paper contributes to a major taxonomic refinement of the squamate faunas during the late Quaternary of northeastern Brazil. All material described here comes from levels with dating around 8,000 years BP, corresponding to the early Holocene. According to Oliveira et al. (in press) the age is consistent with the vertebrate fauna, because representatives of the Pleistocene South American megafauna have not been found in these levels. Like the tayassuids, marsupials, xenarthrans, and caviomorphs from these levels, the squamates do not indicate faunistic alteration during the early Holocene in comparison with the current fauna (Oliveira, 2010; Oliveira et al., in press). The paleoecological data indicated by the taxa reported are in accordance with the mosaic composition of the current environments of the Ubajara region, having humid forest in higher altitudes and open and dryer areas in the plains (Oliveira et al., in press).

\section{ACKNOWLEDGEMENTS}

We thank Conselho Nacional de Desenvolvimento Científico e Tecnológico (CNPq) for financial support of the project "Estudo Paleontológico dos Mamíferos das Cavernas do Parque Nacional de Ubajara, Ceará" (Universal/n $\mathrm{n}^{\circ}$ 473952/2008-4) headed by A.M. Ribeiro (MNC/FZBRS). Thanks also to A.M. Ribeiro (MCN/ FZBRS), G. Lessa (UFV), and S. Teixeira (MUPHI) for help and camaraderie during fieldwork in July 2009; to Fundação Cearense de Apoio à Pesquisa e ao Desenvolvimento Científico e Tecnológico (FUNCAP, BPI 0341-1.07/ 08), and especially to Museu Dom José (MDJ) for the loan 
of the specimens. A.S. Hsiou also thanks to CNPq in the form of Postdoctoral Fellowship ( $\mathrm{n}^{\circ}$. 150803/2010-9); and P.V. Oliveira thanks Coordenação de Aperfeiçoamento de Pessoal de Nível Superior (CAPES) and CNPq for Master and Doctoral Fellowships developed at Programa de PósGraduação em Geociências at UFRGS and UFPE, respectively. We also thank to the three anonymous referees for their careful reviews and helpful suggestions.

\section{REFERENCES}

Albino, A.M., and Carlini, A.A., 2008, First record of Boa constrictor (Serpentes, Boidae) in the Quaternary of South America: Journal of Herpetology, v. 42, p. 82-88.

Auffenberg, W., 1963, The fossil snakes of Florida: Tulane Studies in Zoology and Botany, v. 10, no. 3, p. 131-216.

Ávila-Pires, T.C.S., 1995, Lizards of Brazilian Amazonia (Reptilia: Squamata): Zoologische Verhandelingen, no. 299, 706 p.

Barros-Barreto, C.N.G., De Blasis, P.D., Dias Neto, C.M., Karmann, I., Lino, C.F., and Robrahn, E.M., 1982, Abismo Ponta de Flecha: um projeto arqueológico, paleontológico e geológico no médio curso de Ribeira de Iguape, São Paulo. Revista de Pré-História, v. 3, p. $195-215$.

Brizuela, S., 2010, Los lagartos continentales fósiles de la Argentina (excepto Iguania) [Ph.D. thesis]: La Plata, Faculdad de Ciencias Naturales y Museo, Universidad Nacional de La Plata, 442 p.

Burbrink, F.T., 2005, Inferring the phylogenetic position of Boa constrictor among the Boinae: Molecular Phylogenetics and Evolution, v. 34, p. 167-180. doi:10.1016/j.ympev.2004.08.017.

Camolez, T., and Zaher, H., 2010, Levantamento, identificação e descrição da fauna de Squamata do Quaternário Brasileiro (Lepidosauria): Arquivos de Zoologia, Museu de Zoologia da Universidade de São Paulo, v. 41, p. 1-96.

CPRM (Serviço Geológico do Brasil), 2003, Atlas Digital de Geologia e Recursos Minerais do Ceará, Brasília, Ministério das Minas e Energia, CD-ROM.

Estes, R., 1983, Sauria terrestria, Amphisbaenia, Handbuch der Paläoherpetologie (Teil 10A): Stuttgart, Gustav Fisher Verlag, 249 p.

Estes, R., De Queiroz, K., and Gauthier, A., 1988, Phylogenetic relationships within Squamata, in Estes, R., and Pregill, G., eds., Phylogenetic Relationships of the Lizard Families: Essays Commemorating Charles L. Camp: California, Stanford University Press, p. $119-281$

Estes, R., and Williams, E.E., 1984, Ontogenetic variation in the molariform teeth of lizards: Journal of Vertebrate Paleontology, v. 4, p. 96-107. doi:10.1080/02724634.1984.10011989.

Etheridge, R., 1964, The skeletal morphology and systematic relationships of sceloporine lizards: Copeia, v. 1964, p. 610-631.

Faure, M., Guérin, C., and Parenti, F., 1999, Découverte d'une mégafaune Holocène à la Toca do Serrote do Artur (aire archéologique de São Raimundo Nonato, Piauí, Brésil): Comptes Rendus de l'Académie des Sciences, Ser. II, Sciences de la Terre et des Planètes, v. 329, p. 443-448.

Frost, D.R., 1992, Phylogenetic analysis and taxonomy of the Tropidurus group of lizards (Iguania: Tropiduridae): American Museum Novitates, no. 3033, 68 p.

Frost, D.R., and Etheridge, R., 1989, A Phylogenetic analysis and taxonomy of Iguanian Lizards (Reptilia: Squamata): The University of Kansas, Museum of Natural History, Miscellaneous Publications, no. $81,65 \mathrm{p}$.

Frost, D.R., Etheridge, R., Janies, D., and Titus, T.A., 2001a, Total evidence, sequence alignment, evolution of polychrotid lizards, and a reclassification of the Iguania (Squamata: Iguania): American Museum Novitates, no. 3343, 38 p.

Frost, D.R., Rodrigues, M.T., Grant, T., and Titus, T.A., 2001b, Phylogenetics of the lizard genus Tropidurus (Squamata: Tropiduridae: Tropidurinae): direct optimization, descriptive efficiency, and sensitivity analysis of congruence between molecular data and morphology: Molecular Phylogenetics and Evolution, v. 21, p. 352-371. doi:10.1006/mpev.2001.1015.
Gans, C., and Montero, R., 1998, Two new fossil amphisbaenids (Reptilia: Squamata) from the Pleistocene of Lagoa Santa (Minas Gerais, Brasil): Steenstrupia, v. 24, p. 9-22.

Giugliano, L.G., Contel, E.P.B., and Colli, G.R., 2006, Genetic variability and phylogenetic relationships of Cnemidophorus parecis (Squamata, Teiidae) from Cerrado isolates in southwestern Amazonia: Biochemical Systematics and Ecology, v. 34, p. 383-391. doi:10.1016/ j.bse.2005.12.007.

Giugliano, L.G., Collevatti, R.G., and Colli, G.R., 2007, Molecular dating and phylogenetic relationships among Teiidae (Squamata) inferred by molecular and morphological data: Molecular Phylogenetics and Evolution, v. 45, p. 168-179. doi:10.1016/j.ympev.2007.05.017.

Guérin, C., 1991, La faune de vertébrés du Pléistocène supérieur de l'aire archéologique de São Raimundo Nonato (Piauí, Brésil): Comptes Rendus de l'Académie des Sciences, Ser. II, Sciences de la Terre et des Planètes, v. 312, p. 567-572.

Guérin, C., Curvello, M.A., Faure, M., Hugueney, M., and MourerChauviré, C., 1993, La faune pléistocène du Piauí (Nordeste du Brésil): implications paléoécologiques et biochronologiques: Quaternaria Nova, v. 3, p. 303-341

Henderson, R.W., and Powell, R., 2007, The biology of boas and pythons: a retrospective look to the future, in Henderson, R.W., and Powell, R., eds., Biology of the Boas and Pythons: Eagle Mountain, Utah, Eagle Mountain Publishing, p. 2-22.

Hoffstetter, R., and Gasc, J.P., 1969, Vertebrae and ribs of modern reptiles, in Gans, C., Bellairs, A.d'A., and Parsons, T.S., eds., Biology of the Reptilia, Volume 1, Morphology A: London, Academic Press, p. 201-310.

Holman, J.A., 2000, Fossil Snakes of North America: Origin, Evolution, Distribution, Paleoecology: Bloomington, Indiana University Press, $357 \mathrm{p}$.

Hower, L.M., and Hedges, S.B., 2003, Molecular phylogeny and biogeography of West Indian teiid lizards of the genus Ameiva: Caribbean Journal of Science, v. 39, p. 298-306.

Hsiou, A.S., 2007, A new Teiidae species (Squamata, Scincomorpha) from the late Pleistocene of Rio Grande do Sul State, Brazil: Revista Brasileira de Paleontologia, v. 10, p. 181-194.

Hsiou, A.S., 2010, Lagartos e serpentes (Lepidosauria, Squamata) do Mioceno médio-superior do norte da Região Norte América do Sul [Ph.D. thesis]: Porto Alegre, Universidade Federal do Rio Grande do Sul, $239 \mathrm{p}$.

Hsiou, A.S., and Albino, A.M., 2009, Presence of the genus Eunectes (Serpentes, Boidae) in the Neogene of Southwestern Amazonia, Brazil: Journal of Herpetology, v. 43, p. 612-619. doi:10.1670/08295.1.

Hsiou, A.S., and Albino, A.M., 2010, New snake remains from the Miocene of northern South America: Herpetological Journal, v. 20, p. $249-259$

Hsiou, A.S., and Albino, A.M., 2011, First record of Viperidae snakes from the Pleistocene of southwestern Brazilian Amazonia: Alcheringa, v. 35, p. 389-395. doi:10.1080/03115518.2011.519646.

Hsiou, A.S., de Oliveira, P.V., and Ximenes, C.L., 2009, Presença de Colubroidea (Squamata, Serpentes) no Quaternário da Província Espeleológica de Ubajara, Estado do Ceará, in Livro de Resumos do Congresso Brasileiro de Paleontologia, 21th, Belém, Universidade Federal do Pará/Museu Emílio Goeldi, 189 p.

IBAMA (Instituto Brasileiro do Meio Ambiente e dos Recursos Renováveis), 2002, Parque Nacional de Ubajara: Plano de Manejo, Brasília, Ministério do Meio Ambiente, CD-ROM.

Kluge, A.G., 1989, A concern for evidence and a phylogenetic hypothesis of relationships among Epicrates (Boidae: Serpentes): Systematic Zoology, v. 35, p. 7-25. doi:10.1093/sysbio/38.1.7.

Lee, M.S.Y., and Scanlon, J.D., 2002, Snake phylogeny based on osteology, soft anatomy and ecology: Biological Reviews, v. 77, p. 333-401. doi:10.1017/S1464793102005924.

Lino, C.F., Dias-Neto, C.M., Trajano, E., Gusso, G.L.N., Karmann, I., and Rodrigues, R., 1979, Paleontologia das cavernas do Vale do Ribeira, Exploração I Abismo do Fóssil (SP-145): Resultados parciais, in Atas do Simpósio Regional de Geologia, 2th, Rio Claro, Sociedade Brasileira de Geologia, p. 257-268.

Lund, M., 1840, Nouvelles recherches sur la faune fossile du Brésil: Annales des Sciences Naturelles, Zoologie, ser. 2, v. 13, p. 310-319.

McDiarmid, R.W., Campbell, J.A., and Touré, T.A., 1999, Snakes Species of the World: A Taxonomic and Geographic Reference, Volume 1: Washington D.C., The Herpetologist's League, 511 p. 
Melgarejo, A.R., 2003, Serpentes peçonhentas do Brasil, in Cardoso, J.L.C., França, F.O.S., Wen, F.H., Málaque, C.M.S., and Haddad, Jr., V., eds., Animais Peçonhentos do Brasil: Biologia, Clínica e Terapêutica dos Acidentes: São Paulo, Sarvier, p. 33-61.

Nascimento, D.A. do., Gava, A., Pires, J. de., and Teixeira, W., 1981, Geologia da folha SA. 24 - Fortaleza: Projeto Radambrasil, DNPM, v. 21 , p. $23-212$.

Noonan, B.P., and Chippindale, P.T., 2006, Dispersal and vicariance: the complex evolutionary history of boid snakes: Molecular Phylogenetics and Evolution, v. 40, p. 347-358. doi:10.1016/j.ympev.2006.03.010.

Nydam, R.L., and Cifelli, R.L., 2002, A new teiid from the Cedar Mountain Formation (Albian-Cenomanian boundary) of Utah: Journal of Vertebrate Paleontology, v. 22, p. 276-285. doi:10.1671/ 0272-4634(2002)022[0276:ANTLFT]2.0.CO;2.

Nydam, R.L., Eaton, J.G., and Sankey, J., 2007, New taxa of transverselytoothed lizards (Squamata: Scincomorpha) and new information on the evolutionary history of "teiids": Journal of Paleontology, v. 81, p. 538-549. doi:10.1666/03097.1.

Oliveira, P.V. de., 2010, Mamíferos de Neopleistoceno-Holoceno do Parque Nacional de Ubajara, Ceará [M.S. thesis]: Porto Alegre, Universidade Federal do Rio Grande do Sul, 167 p.

Oliveira, P.V. de., Ribeiro, A.M., Kerber, L., Lessa, G., and Viana, M.S.S., (in press) Late Quaternary caviomorph rodents (Rodentia: Hystricognathi) from Ceará State, northeast Brazil: Journal of Cave and Karst Studies.

Passos, P., 2003, Sistemática do complexo Epicrates cenchria (Linnaeus, 1758), com aproximações sobre a filogenia de Epicrates Wagler, 1830 (Serpentes, Boidae) [M.S. thesis]: Rio de Janeiro, Universidade Federal do Rio de Janeiro, $125 \mathrm{p}$.

Passos, P., and Fernandes, R., 2008, Revision of the Epicrates cenchria complex (Serpentes: Boidae): Herpetological Monographs, v. 22, p. 1-30. doi:10.1655/06-003.1.

Paula-Couto, C., 1978, Mamíferos fósseis do Pleistoceno do Espírito Santo: Anais da Academia Brasileira de Ciências, v. 50, p. 365-379.

Paula-Couto, C., 1980, Fossil Pleistocene to sub-recent mammals from northeastern Brasil: I - Edentata, Megalonychidae. Anais da Academia Brasileira de Ciências, v. 52, p. 144-151.
Pianka, E.R., and Vitt, L.J., 2003, Lizards-Windows to the Evolution of Diversity: Berkeley, University of California Press, series Organisms and Environments 5, $333 \mathrm{p}$.

Presch, W., 1974, A survey of the dentition of the macroteiid lizards (Teiidae: Lacertilia): Herpetologica, v. 30, p. 344-349.

Quadros, M.L.E.S., 1996, Estudo tectono-sedimentar da Bacia de Jaibaras, na região entre as cidades de Pacujá e Jaibaras, noroeste do Estado do Ceará [M.S. thesis]: Belém, Universidade Federal do Pará, $134 \mathrm{p}$.

Rage, J.-C., 1984, Serpentes, Handbuch der Paläoherpetologie, Part 11: Stuttgart, Gustav Fisher Verlag, 80 p.

Rage, J.-C., 2001, Fossil snakes from the Paleocene of São José de Itaboraí, Brazil. Part II. Boidae: Palaeovertebrata, v. 30, p. 111-150.

Reeder, T.W., Cole, C.J., and Dessauer, H.C., 2002, Phylogenetic relationships of whiptail lizards of the genus Cnemidophorus (Squamata: Teiidae): a test of monophyly, reevaluation of karyotypic evolution, and review of hybrid origins: American Museum Novitates, no. 3365, $61 \mathrm{p}$.

Szyndlar, Z., and Rage, J.-C., 2003, Non-erycine Booidea from the Oligocene and Miocene of Europe: Kraków, Institute of Systematics and Evolution of Animals, Polish Academy of Sciences, 109 p.

Trajano, E., and Ferrarezzi, H., 1995, A fossil bear from northeastern Brazil, with a phylogenetic analysis of the South American extinct Tremarctinae (Ursidae): Journal of Vertebrate Paleontology, v. 14, p. 552-561. doi:10.1080/02724634.1995.10011577.

Wüster, W., Ferguson, J.E., Quijada-Mascareñas, A., Pook, C.E., Salomão, M.C., and Thorpe, R.S., 2005, Tracing an invasion: landbridges, refugia, and the phylogeography of the Neotropical rattlesnake (Serpentes: Viperidae: Crotalus durissus): Molecular Ecology, v. 14, p. 1095-1108. doi:10.1111/j.1365-294X.2005.02471.x.

Ximenes, C.L., and Machado, D.A.N., 2004, Diagnóstico paleontológico da Província Espeleológica de Ubajara, Estado do Ceará, in Resumos do Encontro Brasileiro de Estudos do Carste, 1th, Belo Horizonte: Redespeleo Brasil e Associação Brasileira de Águas Subterrâneas (ABAS), $40 \mathrm{p}$.

Zaher, H., 1999, Hemipenial morphology of the South American xenodontine snakes, with a proposal for a monophyletic Xenodontinae and a reappraisal of colubroid hemipenes: Bulletin of the American Museum of Natural History, no. 240, 168 p. 